\title{
Analysis of Gas-Geodynamic Phenomena During the Preparatory and Mining Works in Seam 358/1 at KWK "Budryk"
}

\author{
Marian Zmarzły \\ JSW S.A. KWK „Jastrzębie-Bzie”, Poland \\ Michał Schubert \\ JSW S.A. KWK „Budryk”, Poland \\ Krystian Salamon
}

JSW S.A. KWK „Borynia-Zofiówka” Ruch Zofiówka, Poland

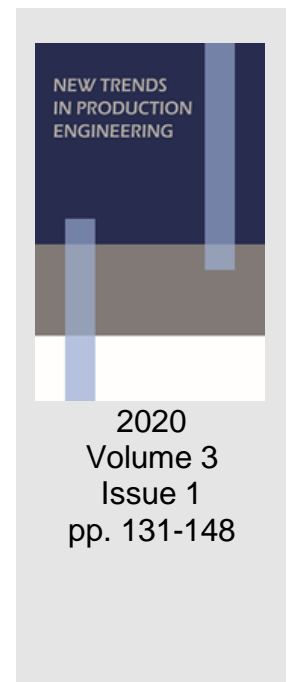

Date of submission to the Editor: 02/2020

Date of acceptance by the Editor: 03/2020

\section{INTRODUCTION}

Preparatory and exploitation works in hard coal mines are particularly difficult due to the fact that mining is one of the industries where work traditionally involves high occupational risk. Safe exploitation of coal is endangered by numerous natural threats, including the methane hazard, the gas and rock outburst threat as well as frequent tectonics. The complexity of gas-dynamic and gas-geodynamic phenomena in the mines of Jastrzębska Spółka Węglowa, i.e. "Pniówek" (former "XXX-lecia PRL") and "Zofiówka" (former "Manifest Lipcowy") results from many factors and parameters characterizing these threats. They include factors occurring in natural conditions and those associated with the mining process.

There is a close relationship between the methane hazard and the threat of gas and rock outbursts. The gas and rock outburst threat is defined as a natural tendency of gas-geodynamic phenomena to occur in the form of gas and rock outbursts or a sudden outflow of gas from the rock mass into the excavation. The growing methane-bearing capacity of a deposit as well as reduced coal gas permeability due to the increasing exploitation pressure causes that this threat increases and begins to be observed in other parts of the Upper Silesian Coal Basin. An example is "Budryk" coal mine, where recently not only a parametric increase in the methane and outburst hazard has been recorded, but also gasgeodynamic phenomena occurred during the exploitation of seam 358/1. A similar growth in risk has been noted in recent years in "KnurówSzczygłowice" Ruch "Szczygłowice", where in the process of driving the test gallery $16 \mathrm{~b}$ in seam $407 / 3$ and carrying out anti-burst preventive works, more than 70 methane outflows were recorded, mostly as a result of blasting.

From the point of view of natural hazards occurrence, it is always a great unknown to perform works in new seams and parts of the deposit, and, in consequence, in the rock mass in which the natural balance of the deposit 
is disturbed, with the state of stresses changing versus time and tectonics that has not been fully identified. Such conditions will prevail in the years to come in the major investment of Jastrzębska Spółka Węglowa, namely the construction of a new mining plant "Jastrzębie-Bzie" in Bzie-Dębina mining area.

The publication highlights the importance of conducting a continuous analysis of the risk of outburst and its multi-parametric evaluation, taking into account factors and parameters that describe the physical, mechanical, gas, tectonic and mining properties influencing the gas and rock outburst hazard in hard coal mines. The results of investigations and experience gained in the field of facility maintenance enable increasing the accuracy of assessing the degree of the gas and rock outburst threat, but do not provide a one-hundred percent possibility to predict the occurrence of gas-dynamic or gas-geodynamic phenomena, which reduces the safety of workers employed in mines.

\section{EVALUATION OF GAS-DYNAMIC AND GAS-GEODYNAMIC PHENOMENA IN THE MINES OF JASTRZĘBSKA SPÓŁKA WĘGLOWA}

The analysis of the phenomena occurring in the mines of Jastrzębska Spółka Węglowa (Majcherczyk T., Jakubów A., 2007, Wasilewski St., Zmarzły M. 2018, Jakubów A., Tor A., Tobiczyk St. 2003, Tor A., Jakubów A. 2006, Wasilewski St. 2009, Zmarzły M. 2017), and the methods used to forecast the hazard of gas and rock outburst indicates the need to continuously strive to increase the safety of works and introduce solutions improving the accuracy of outburst risk assessment. What the major incidents in "Pniówek" and "Zofiówka" mines had in common was that they occurred in seams which were not considered to be endangered or prone to gas-geodynamic phenomena. Fig. 1 presents the effects of the outburst on $22^{\text {nd }}$ November, 2005, in transport gallery D-6, seam $409 / 4$, where 16 workers were employed.

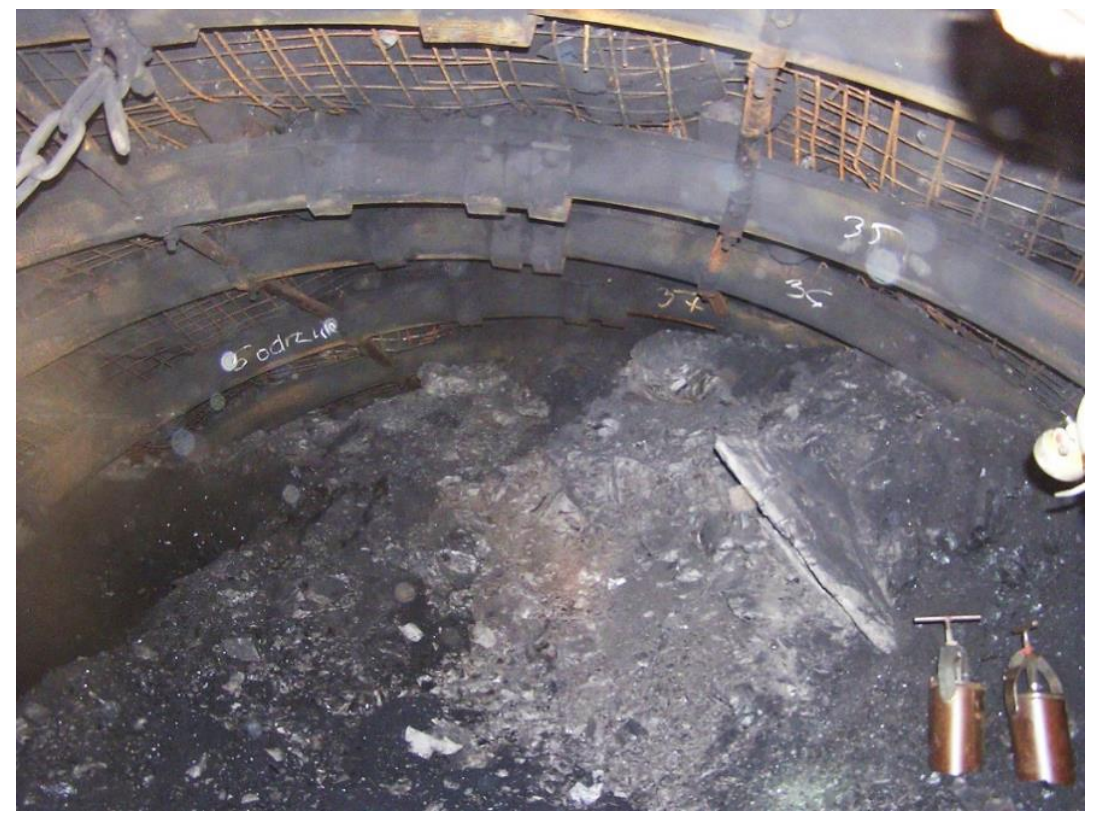

Fig. 1 Heading face after the outburst of gases and rocks in transport gallery D-6, seam 409/4 - "Zofiówka" mine (November 22, 2005) 
During the excavations conducted with the AM-50 road header, approximately $350 \mathrm{Mg}$ of crushed mined rock was thrown into area near the working face, which formed a heap of approx. $30 \mathrm{~m}$ in length. Three employees - the cutter loader operator and two miners were killed.

The principle of classifying seams and their parts in particular methane outburst hazard categories was based on the results of the following tests carried out in the mines: methane-bearing capacity, coal hardness and methane desorption intensity, or on incidents (outbursts or outflows) and symptoms indicating an increased risk of gas and rock outbursts.

Methane-bearing capacity is the most important parameter for assessing the risk of outburst in coal basins all over the world. It is laboratory-determined after taking "in situ" samples. Further criteria for the ongoing assessment of the methane and rock outburst threat are simple, and, as such, can be assessed by mine services without the need for laboratory equipment. Measurement of coal hardness according to Protodiaconow, conducted by the crushing method, shows the relationship between hardness and the structure of coal, which is a very important factor for evaluating the state of emergency in Polish hard coal mines, as shown by the incidents in "Pniówek" and "Zofiówka" mines. In the case of coals from regions in the immediate vicinity of the outburst, the value of this indicator ranges from 0.1 to 0.3 on the Protodiaconow scale. Desorbometric measurements are used in the mining industry in many countries (e.g. Poland, Germany, Czech Republic, China). Their basic advantage is the simplicity of implementation and the promptness of result (Stączek A, Simka A, 2004). The results of desorbometric measurements are obtained directly at the place of their performance. Well-done measurements provide a useful result and are frequently the first, most important criterion determining the performance of works in view of the outburst hazard. An important criterion is also identification of threat symptoms during excavation works which are specified in the regulations. Such symptoms provide an additional proof of an increased hazard. After the incidents in JSW S.A., the mines carrying out works in seams endangered with outbursts, upon their own initiative introduced additional restrictions and increased the frequency of measurements and tests, irrespective of the legal regulations in force (WUG, 2006, WUG, 2007). The rigours regarding works, which were initially changed by internal regulations (after the outburst in 2005 in "Zofiówka" coal mine), eventually resulted in the adoption of new regulations (Rozporządzenie Ministra Środowiska z dnia 29 stycznia 2013).

The gas-geodynamic phenomena observed in JSW S.A. necessitate a rigorous approach to the conductance of works in view of the existing threat of gas and rock outburst and make it necessary to look for new technical and organizational solutions so as to ensure mining teams' safety. 
DANGEROUS GAS-GEODYNAMIC INCIDENTS DURING WORKS IN "BUDRYK" KWK (JSW S.A. KWK „Budryk”)

Drilling of preparatory headings in view of the recorded increase in the methane and outburst hazard

In the last decade, a significant increase in the methane hazard as well as the gas and rock outburst threat was recorded during the works in "Budryk" mine, which in 2008 was incorporated into the structures of JSW S.A. It is one of the youngest Polish hard coal mines, located in Ornontowice, Silesian Province, the County of Mikołów. Construction works began in 1979. The mining panel has an area of $35.97 \mathrm{~km}^{2}$ and lies in the centre of the Upper Silesian Coal Basin. In 2012, ramp D in seam 358/1 turned out to be a particularly dangerous working. Fig. 2 presents the value of methane-bearing capacity of seam 358/1 in the area of ramp $\mathrm{D}$. The maximum value of methane-bearing capacity of seam $358 / 1$ in this area of ramp D before the outburst reached max. $13,206 \mathrm{~m}^{3} / \mathrm{Mg}_{\mathrm{csw}}$, whereas the maximum value of desorption intensity was $1.88 \mathrm{k} \mathrm{Pa}$.

The incident happened on 11.05.2012 at $19^{42}$. The outburst of methane and rocks occurred in the working face of the excavated ramp $D$ in seam 358/1 on the level of $1050 \mathrm{~m}$. Seam 358/1, having a thickness of $1.5 \mathrm{~m}$ to $2.1 \mathrm{~m}$, was categorized as class B coal dust explosion hazard, I class water hazard and IV (the highest) class of methane hazard.

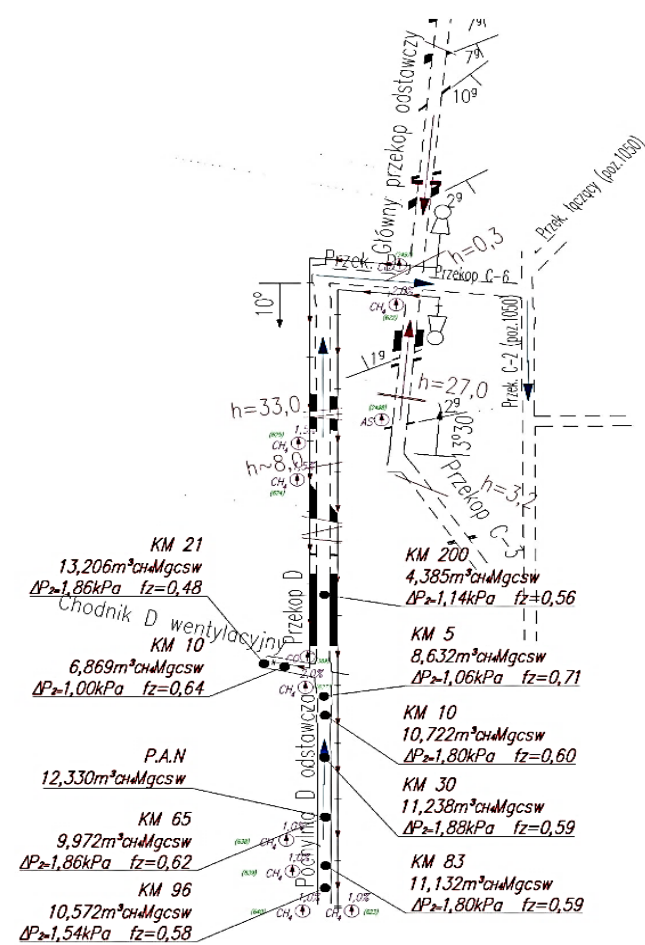

Fig. 2 Values of the methane-bearing capacity of seam 358/1 in the vicinity of the excavated ramp D

At that time, seam 358/1 was not classified as threatened with outbursts, but the works were carried out under conditions corresponding to the then category of methane and rock outburst hazard, while introducing additional restrictions and prophylactics: 
- a special zone of the methane and rock outburst hazard was designated in the excavation - the maximum number of employees staying in the working could not exceed 30 persons per shift,

- as the excavating works advanced, two 6-meter long test holes were made once a day to determine the desorption index and the hardness ratio,

- at intervals of 50 metres of the working advance, but at least once a week, methane-bearing capacity in the working was determined,

- every 30 meters of the working advance, a gas sample was taken from the 3-metre test hole for chemical analysis,

- in order to identify the threat on an ongoing basis, test holes were made ahead of the face at intervals of no less than $10.0 \mathrm{~m}$,

- relieving shooting was performed in the test holes,

- detailed principles of driving the workings were specified in the "Technology of Forecasting the Methane and Rock Outburst Hazard in Ramp D in Seam $358 / 1 "$,

- the employed crew were trained to identify the symptoms and follow the procedure in the case of the methane and rock outburst hazard,

- an additional fan supplied with compressed air was installed in the face of the excavated working.

During the incident, 17 employees were carrying out excavating works. As a result of the outburst, approximately $340 \mathrm{~m}^{3}$ of methane with ca $35 \mathrm{~m}^{3}$ of fine coal was thrown into the zone near the face; the coal formed a heap in the working face over a length of approximately $3.5 \mathrm{~m}$ and a height of ca $2.75 \mathrm{~m}$. Figure 3 shows the values of methane concentrations recorded by the automatic methanometric sensors during the outburst in ramp D of seam 358/1.

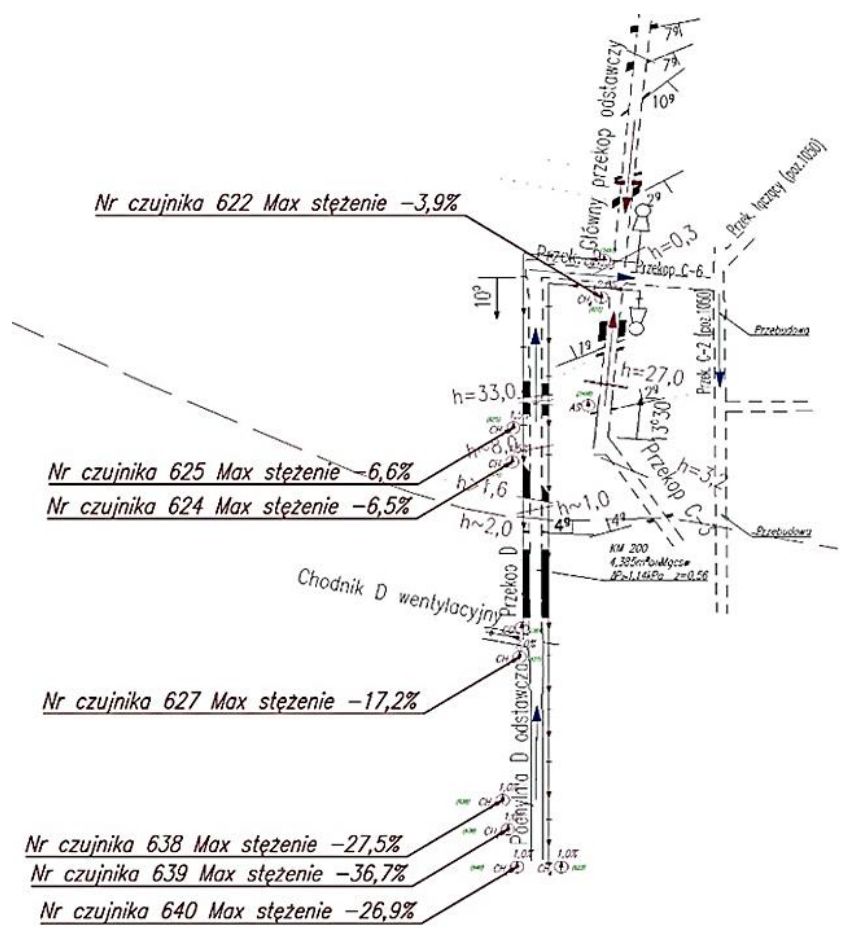

Fig. 3 Methane concentrations during the outburst in the area of ramp D in seam 358/1 
The maximum methane content recorded by the sensors in the face reached $36.7 \%$. The workers employed in ramp $D$ and tunnel $D$ retreated to the flow of air without using escape apparatuses. None of the workers sustained injuries. Despite introducing a number of rigours and preventive measures, there was an outburst of gases and rocks. The view of the heading face after the outburst in ramp $D$ in seam 358/1 has been presented in Figures 4 and 5.

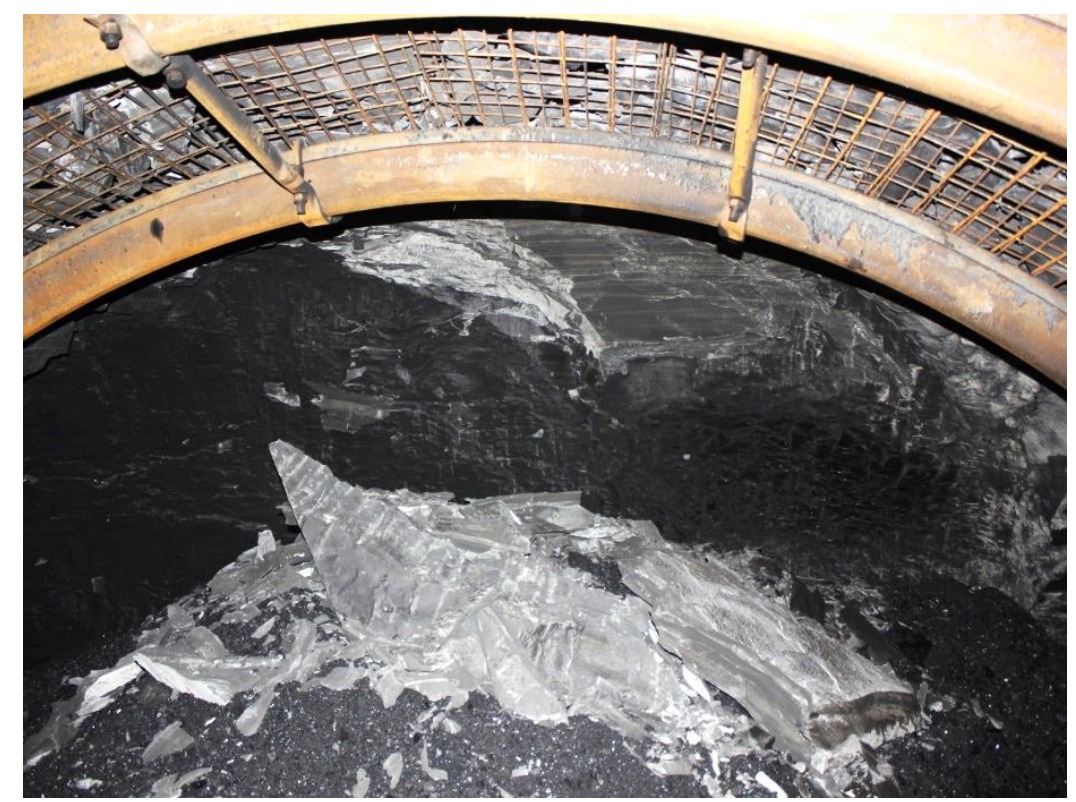

Fig. 4 Heading face after the outburst of gases and rocks in ramp $D$ in seam 358/1 (11.05.2012)

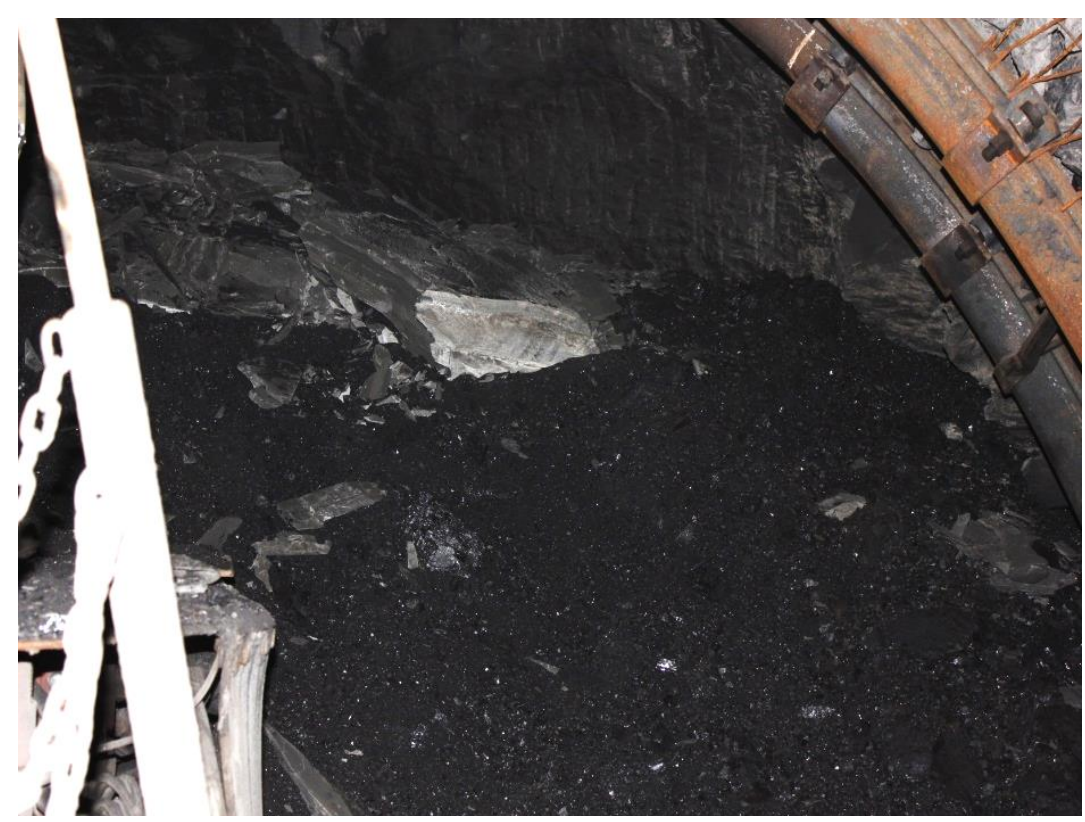

Fig. 5 Heading face after the outburst of gases and rocks in ramp $D$ in seam 358/1 (11.05.2012)

This was the first incident that showed how difficult the area in "Budryk" coal mine was in terms of both methane and outburst hazards, as demonstrated by the subsequent exploitation of the first longwall in this part of the deposit. 


\section{Mining and geological conditions during mining operations in longwall D-1 seam 358/1}

The part of longwall "D" in seam 358/1 where the outburst occurred in ramp $D$ is located in the southern part of "Ornontowice I" mining area. Part "D" of seam $358 / 1$, from the south-east is limited by the boundary of "Łaziska II" mining area. The south-west border of part "D" is "Dębieńsko 1" OG, while from the northwest it is "Knurów" OG. From the north, part "D" of seam 358/1 is limited by "Barbara" fault zone with a generally parallel course and a throw of approx. $45 \div 60 \mathrm{~m}$ on $\mathrm{S}$ and SW. In the central area of part "D" there is a fault with a WE course and a throw of approx. $22 \div 45 \mathrm{~m}$ on $\mathrm{N}$ called "Dębieński" fault. In the central part of part " $\mathrm{D}$ " there are also faults with a generally meridional course and throws of approx. $0.2 \div 3.4 \mathrm{~m}$ on $\mathrm{W}$ or $\mathrm{E}$.

Seam $358 / 1$ in the area of the longwall was identified with the workings made: ramp $D$, gallery $D$, gallery D-1, development of longwall D-1 and one surface borehole G.Or.26 (1963).

Longwall D-1 exploited seam 358/1 from the development of D-1 southeast. The seam in this area generally subsides on SW and S (locally on $E$ and SE) at an angle of 0 to $8^{\circ}$ (locally up to $10^{\circ}$ ). The entire panel length of longwall D-1 in seam 358/1 was to reach $985 \mathrm{~m}$. Longwall D-1 was driven in seam 358/1 having a thickness of $1.0 \div 3.0 \mathrm{~m}$ (including coal layers above seam 358/1). Lithologically, the seam was built of a coal layer having a thickness of $1.00 \div 3.00 \mathrm{~m}$ with the overlying layers. Locally, in the vicinity of longwall-D-1 development, seam 358/1 had a thickness of approximately $1.0 \mathrm{~m}$.

Due to tectonic disturbances in the area and stratification occurring during the mining works, longwall D- it was expected to contain sandy shale or fine-grained sandstone, i.e. rocks with a medium or high propensity for sparking which causes the ignition of methane.

\section{Roof conditions}

In the roadways of longwall D-1 (i.e. gallery $D$ and gallery D-1) above seam $358 / 1$ there were mostly deposits of shale.

Directly above seam 358/1 in borehole G.Or.26 (1963), a 10.8m thick shale layer was found; above it there was a $0.3 \mathrm{~m}$ thick layer of coal (seam 357)

In borehole G2 (2015), directly above seam 358/1, the following deposits were found, respectively: $0.3 \mathrm{~m}$ argillaceous shist, $0.65 \mathrm{~m}$ sandstone, $1.15 \mathrm{~m}$ clay and $2.25 \mathrm{~m}$ sandstone. Above, alternate layers of argillaceous shist, fine-grained sandstone and sandy shale with a total thickness of more than $8.85 \mathrm{~m}$ were deposited.

\section{Floor conditions}

In the roadways of longwall D-1 (i.e. gallery D, gallery D-1) directly under seam 358/1 the following were found:

- sandy shale in the floor of gallery $D$, over the whole length of the heading, locally with shale interbeddings,

- shale in gallery D-1, with local interbeddings of sandy shale and sandy shale. 
In borehole G.Or.26 (1963), under seam 358/1, in the heading floor there was a layer of shale having a thickness of $1.8 \mathrm{~m}$, followed by a $3.9 \mathrm{~m}$ layer of sandy shale. Below, a deposit of shale having a thickness of $13.2 \mathrm{~m}$ was found. Under seam $358 / 1$, within a distance of approximately $18.9 \mathrm{~m}$, a ca $2.0 \mathrm{~m}$ thick seam $360 / 1$ was discovered. Below seam 358/1 and the underneath deposit of shale, in borehole G4(2017), there was a layer of shale with fine-grained sandstone overgrowth having a total thickness of $7.4 \mathrm{~m}$. Below, the following layers were found: $0.9 \mathrm{~m}$ sandy shale, $1.5 \mathrm{~m}$ fine-grain sandstone and $6.6 \mathrm{~m}$ shale. Below seam $358 / 1$, within a distance of approx. $16.4 \mathrm{~m}$, a ca $1.1 \mathrm{~m}$ thick seam $360 / 1$ was found.

In borehole G3 (2017) below seam 358/1, there is a layer of shale with a thickness of $1.5 \mathrm{~m}$. Underneath there are alternate layers of sandy shale, shale and sandstone with a total thickness of $11.9 \mathrm{~m}$. Below seam 358/1, within a distance of approx. $13.4 \mathrm{~m}$, an approximately $0.7 \mathrm{~m}$-thick seam 360/1 was found.

\section{Propensity of rocks to ignite methane}

Generally, in the longwall section in the vicinity of seam 358/1, the deposits of shale, sandy shale and, locally, sandstones were expected to be found. Therefore, in the entire longwall panel, the possibility of finding rocks characterized by low and high propensity to ignite methane was taken into account. The propensity of rocks to ignite methane was determined on the basis of the general classification of rocks in terms of the mechanical sparks risk during mechanical mining works according to mining regulations in force in Poland [8].

\section{Methane explosion and outburst risk during mining works in Longwall D-1 seam 358/1}

Due to the fact that the exploitation of seam 358/1 with Longwall D-1 was to be carried out above the access level (level 1158), the "Analysis of a potential ventilation network diagram during the exploitation of seam 358/1 with Longwall D-1 with particular focus on ventilation stability" was prepared. Taking into account the conclusions contained in this study and the occurring natural hazards, it was assumed that Longwall D-1 would be ventilated into seam 358/1 by the "Y" method, with the exhaust air being removed along the goafs to shaft II, level 1050.

Upon the order of the Ventilation Department of JSW S.A. KWK "Budryk", a dynamic forecast of absolute methane-bearing capacity for the area of Longwall D-1 in seam 358/1 was prepared by Przedsiębiorstwo Odmetanowania Kopalń "Zachód" sp. z o. o. Table 1 presents the values of the predicted methane-bearing capacity in the longwall area depending on the output.

This forecast and instruction No. 17 - "Principles of longwall driving under methane hazard conditions" (GIG October 2004) provided the basis for adopting a procedure to carry out the project of longwall ventilation under methane hazard conditions and selecting appropriate measures to counteract the methane 
threat. According to the conclusions of the "Dynamic Forecast of Absolute Methane-Bearing Capacity in the Area of Longwall D-1 in seam 358/1 in KWK "Budryk", in the event the actual value of absolute methane-bearing capacity is $30 \%$ higher than the forecasted one, the forecast had to be verified.

Table 1 Forecast of methane-bearing capacity in the area of Longwall D-1 in seam $358 / 1$

\begin{tabular}{||c||c|c|c|c|c|c|c|c|c|c||}
\hline $\begin{array}{c}\text { Output } \\
\text { (t/d) }\end{array}$ & $\begin{array}{c}\text { For panel } \\
\text { length }\end{array}$ & $\mathbf{1 0 0 0}$ & $\mathbf{1 5 0 0}$ & $\mathbf{2 0 0 0}$ & $\mathbf{2 5 0 0}$ & $\mathbf{3 0 0 0}$ & $\mathbf{3 5 0 0}$ & $\mathbf{4 0 0 0}$ & $\mathbf{4 5 0 0}$ & $\mathbf{5 0 0 0}$ \\
\hline \hline $\begin{array}{c}\mathrm{m}^{3} \mathrm{CH}_{4} / \\
/ \mathrm{min}\end{array}$ & $\begin{array}{c}\text { From the } \\
\text { beginning } \\
\text { to } 200 \mathrm{~m}\end{array}$ & 29.50 & 38.73 & 47.02 & 54.67 & 61.84 & 68.64 & 75.14 & 81.38 & 87.41 \\
\hline $\begin{array}{c}\mathrm{m}^{3} \mathrm{CH}_{4} / \\
/ \mathrm{min}\end{array}$ & $\begin{array}{c}\text { from200m } \\
\text { to } 800 \mathrm{~m}\end{array}$ & 33.95 & 44.53 & 54.02 & 62.79 & 71.01 & 78.81 & 86.26 & 93.41 & 100.32 \\
\hline $\begin{array}{c}\mathrm{m}^{3} \mathrm{CH}_{4} / \\
/ \mathrm{min}\end{array}$ & $\begin{array}{c}\text { from 800m } \\
\text { to the end }\end{array}$ & 34.73 & 45.53 & 55.24 & 64.20 & 72.60 & 80.57 & 88.18 & 95.49 & 102.55 \\
\hline \hline
\end{tabular}

Taking into account the conditions, it was established that exploitation of longwall D-1 in seam 358/1 would be accompanied by the rock mass methane drainage, in accordance with the developed "Technical Project of Methane Drainage from Longwall D-1 in seam 358/1 in JSW S.A. KWK "Budryk" approved by KRZG. Drainage holes will be grouped into bundles of holes, successively drilled behind the face advance from longwall D-1 in seam 358/1. Methane from the methane holes behind the longwall front will be recovered by the pipeline in longwall D-1 in seam $358 / 1$ and directed to the pipeline in ramp D.

\section{GAS AND ROCK OUTBURST HAZARD}

Longwall D-1 was mined in seam 358/1, which in area D was classified as III degree gas and rock outburst hazard. KWK "Budryk" had the study "Forecast of the gas and rock outburst threat for longwall D-1 in seam 358/1" prepared by an expert, which said that:

- previous experiences in GZW indicate no risk of gas and rock outbursts in the workings. This is, among others, due to the presence of a zone of cracks near the side wall which cause coal degassing and shifting the maximum methane pressures deep into the rock mass. Gas and rock outbursts are often associated with the occurrence of gas pockets in the region of tectonic disturbances. In the case of longwall D-1 in seam 358/1, this type of hazard should not be expected. Faults found during mining works are "unobstructed" for methane; they caused the rock mass to degass around the fault gaps, which resulted in decreased methane pore pressure.

- the only sections where the threat of gas-geodynamic phenomena (which may manifest themselves mainly in increased ventilation methane-bearing capacity) in Longwall D-1 might occur are the parts of the seam contained in the range from $400 \mathrm{~m}$ to approximately $500 \mathrm{~m}$, from ramp $\mathrm{D}$ along gallery D, and over a distance of ca $500 \mathrm{~m}$ up to $900 \mathrm{~m}$ along Gallery D-1, and 
on the final section of the exploited longwall. In particular, this applies to the lower section of the longwall, where the sorption properties of coal are slightly worse. In the remaining sections of Longwall D-1 there is no risk of gasgeodynamic phenomena, especially gas and rock outbursts.

Based on experiences related to the exploitation of seam 401 with longwalls B-9, B-10 and B-11 in the part of seam 401 classified as category III of gas and rock outburst hazard, and on the assessment of gas and rock outburst threat on the basis of the results of measurements carried out in the face workings, it could be concluded that the planned exploitation of seam 358/1 with Longwall D-1 would be carried out under conditions of high primary methane saturation. However, the use of a chock powered support in longwall D-1 will result in the formation of a Trompeter's zone in the excavation front with a reduced outburst potential (the so-called buffer zone). Maintaining the buffer zone ahead of longwall D-1 was to exclude the possibility of an outburst or other gas-aerodynamic phenomena in the longwall.

Considering the above, the prophylactic measures recommended in the "Technology for forecasting and combating the risk of gas and rock outbursts during exploitation of Longwall D-1 in seam 358/11" were observed during the exploitation of seam 358/1 with Longwall D-1.

This technology, among others, specified the following:

- responsibilities of the mining supervision staff,

- evaluation of risk and measuring methods,

- principles of counteracting the threat of gas and rock outburst in the longwall,

- records of persons staying in the zone,

- high-risk area, where only a specified number of people can stay.

Increased methane hazard in the final section of Longwall D-1 seam 358/1 During the exploitation of the final section of Longwall D-1, seam 358/1, in the vicinity of ramp $D$ (in which an outburst occurred in 2012) there were numerous methane outflows. The mining situation in Longwall D-1 seam 358/1 in its final section has been shown in Fig. 6 .

On 19.12.2018, at approximately 7 p.m., the permissible methane concentrations recorded by the automatic methanometric sensors in the area of Longwall D-1 in seam 358/1 were exceeded, after the mining machines had left the area, which caused a sudden roof fall in sections 70-80 and an outflow of an increased amount of methane from the goafs to the space of Longwall D-1 in seam 358/1. As a result of this incident, the following exceeded concentrations of methane were recorded by:

- sensor No. 773 (Longwall D-1 under the face conveyor extension) - max. $11.4 \%$ (2min. $12 \mathrm{sec}$.),

- sensor No. 774 (Longwall D-1 in a distance of 2-3m from Gallery D-1) - max. $8.3 \%$ (4 min. 20 sec.),

- sensor No. 775 (Gallery D-1 in a distance of $2-5 \mathrm{~m}$ to the west from the powered support roof bar) - max. 4.3\% (3 min. $41 \mathrm{sec}$.), 
- sensor No. 759 (Gallery D-1 in a distance of ca $50 \mathrm{~m}$ to the west from the longwall) - max. 3.2\% (3 min. $53 \mathrm{sec}$.),

- sensor No. 777 (Gallery D-1 in a distance of max. $50 \mathrm{~m}$ to the west from the beginning of the longwall - max. 2.2\% (2 min. $55 \mathrm{sec}$.),

- sensor No. 778 (Gallery D-1 within a distance of max.10 m from Ventilation Ramp D) - max. 2.0\% (1 min. 59 sec.),

- sensor No. 779 (Ventilation Ramp D in a distance of ca $10 \mathrm{~m}$ to the north of Gallery D-1) - max. 2.0\% (54 sec.).

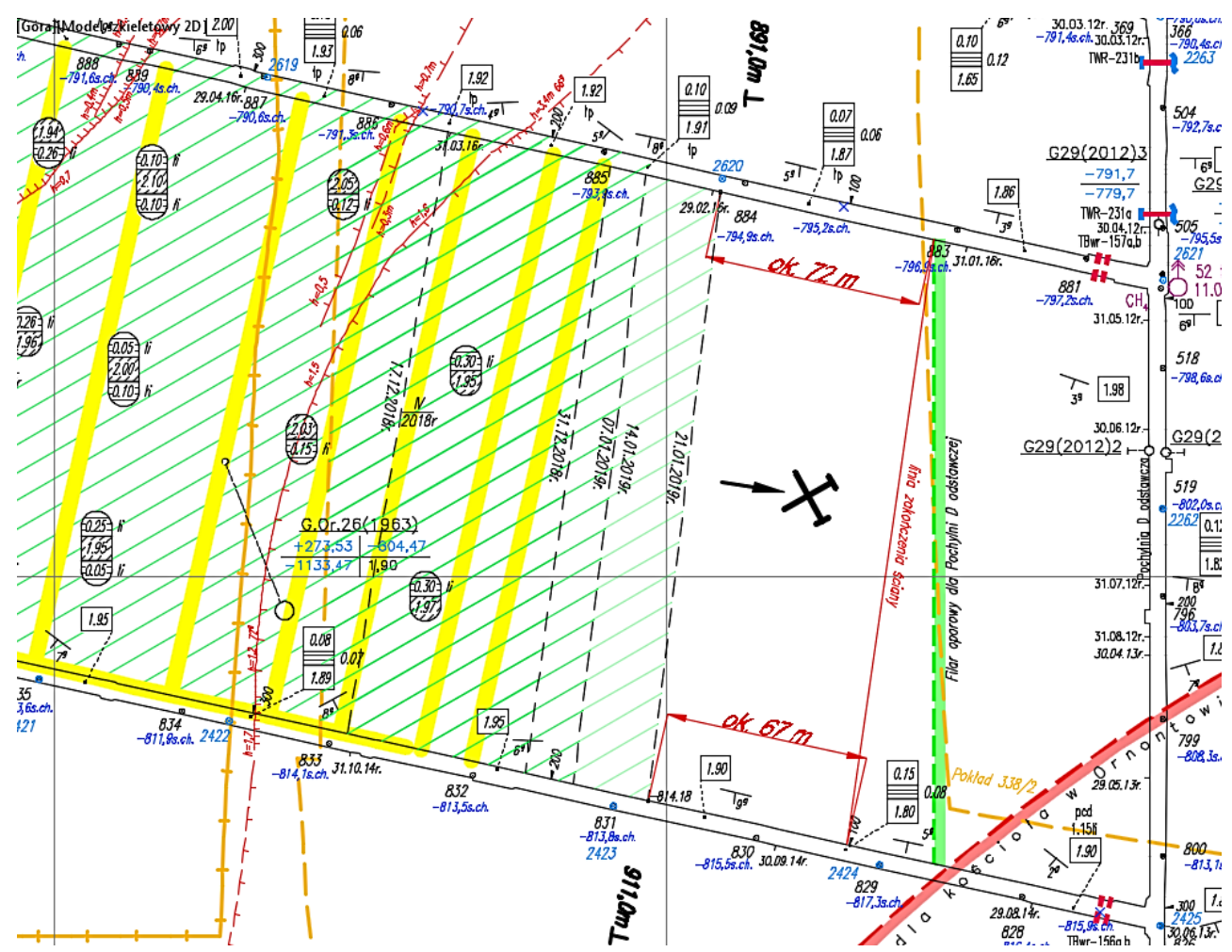

Fig. 6 Fragment of the map showing the area of Longwall D-1 in seam $358 / 1$ in its final section

The amount of methane released was ca $65 \mathrm{~m}^{3} \mathrm{CH}_{4}$. The above incident also influenced the value of criterial methane-bearing capacity, which on 19.12.2018 was lower than absolute methane-bearing in the area of the longwall, reaching $50.7 \mathrm{~m}^{3} \mathrm{CH}_{4} / \mathrm{min}$, whereas the calculated criterial methane-bearing capacity was $48 \mathrm{~m}^{3} \mathrm{CH}_{4} / \mathrm{min}$.

On December 21, 2018 at 18.01 the value of permissible methane concentration was exceeded on the automatic methanometric sensor No. 773 (Longwall D-1 under the face conveyor extension) with a maximum concentration of $9.6 \% \mathrm{CH}_{4}$. The exceedance lasted 2 minutes 5 seconds. The above exceedance occurred after the mining machines left the area and the caving was filled behind the powered support units, which caused an outflow of an increased amount of methane from the goafs to the working space of Longwall D-1 in seam 358/1. For the same reason, at. $23^{36}$ the permissible methane concentrations were exceeded on the automatic methane measurement sensors in the area of Longwall D-1 in seam 358/1: 
- sensor No. 773 (Longwall D-1, under the face conveyor extension) - max. $12.1 \%$ (2 min. 59 sec.),

- sensor No. 774 (Longwall D-1, in a distance of 2-3 m from Gallery D-1) - max. 9.3\% (3 min. $52 \mathrm{sec}$.),

- sensor No. 775 (Gallery D-1, in a distance of 2-5 $\mathrm{m}$ to the west from the powered support roof bar) - max. $7.9 \%$ (5 min. $9 \mathrm{sec}$.),

- sensor No. 759 (Gallery D-1 in a distance of approx. $50 \mathrm{~m}$ to the west of the longwall) - max. $3.7 \%$ (5 min. 5 sec.),

- sensor No. 777 (Gallery D-1, in a distance of max. $50 \mathrm{~m}$ to the west from the beginning of the longwall) - max. 2.7\% (7 min. $23 \mathrm{sec}$.),

- sensor No. 778 (Gallery D-1, in a distance of max.10 m from the Ventilation Ramp) - max. 2.5\% (6 min. 3 sec.),

- sensor No. 779 (Ventilation Ramp D, in a distance of ca $10 \mathrm{~m}$ to the north from Gallery D-1) - max. 2.3\% (3 min. $14 \mathrm{sec}$.).

The amount of methane released in the above incident was determined as approximately $57 \mathrm{~m}^{3} \mathrm{CH}_{4}$. The incident had also an impact on the criterial methane-bearing capacity on $21.12 .2018\left(39 \mathrm{~m}^{3} \mathrm{CH}_{4} / \mathrm{min}\right.$.), which was lower than the absolute methane-bearing capacity of the longwall $\left(56 \mathrm{~m}^{3} \mathrm{CH}_{4} / \mathrm{min}\right)$.

In December 2018 the average methane-bearing capacity in the longwall area reached $49.9 \mathrm{~m}^{3} \mathrm{CH}_{4} / \mathrm{min}$; methane capture ranged from 22.8 to $32.5 \mathrm{~m}^{3}$ $\mathrm{CH}_{4} /$ min, which means that the average efficiency of methane drainage was ca $55 \%$. Taking into consideration the maximum value of absolute methanebearing capacity in the longwall area, which on 24.08 .2018 reached $102.7 \mathrm{~m}^{3}$ $\mathrm{CH}_{4} / \mathrm{min}$, it should be concluded that the absolute methane-bearing capacities in the longwall area in the current month are relatively low compared to the previously recorded maximum values in Longwall D-1 in seam 358/1.

On 4.01.2019, at approx.1147, exceeded values of permissible methane concentrations were recorded by the automatic methanometric sensors in the area of Longwall D-1 in seam 358/1, due to an increased release of methane after a lump of coal measuring $3.0 \mathrm{~m} \times 1.6 \mathrm{~m} \times 0.5 \mathrm{~m}$ slid in the vicinity of section $93-94$. As a result of this incident, the following exceeded values of permissible methane concentration were recorded:

- sensor 773 (Longwall D-1 under the face conveyor extension) - max. 11.4\% (49 sec.),

- sensor No. 774 (Longwall D-1 in a distance of 2-3 m from Gallery D-1) - max. $7.7 \%$ (6 min. 47 sec.),

- sensor No. 775 (Longwall D-1 in a distance of 2-5 $\mathrm{m}$ to the west of the powered support roof bar) - max. $4.4 \%$ (4 min. $7 \mathrm{sec}$.),

- sensor No. 759 (Gallery D-1 in a distance of approx. $50 \mathrm{~m}$ to the west of the longwall) - max. $2.5 \%$ (1 min. $46 \mathrm{sec}$.).

The amount of methane released was ca $76 \mathrm{~m}^{3} \mathrm{CH}_{4}$.

Due to the high values of methane-bearing capacity in the discussed area, a decision was taken to start additional methane drainage collections over the last $100 \mathrm{~m}$ of the panel length. The diagram of the methane drainage bores 
deployment is shown in Fig. 7. Five methane drainage collections were carried out in the seam, two in boreholes at a mutual distance of approx. $24 \mathrm{~m}$ and a length of apertures of approx. $70 \mathrm{~m}$. During the meeting of the Mine's Team for Identifying and Counteracting Methane Threat on 04.01.2019, a decision was taken to increase the number of methane drainage holes between the existing collections in Gallery D with parameters analogous to those previously made.

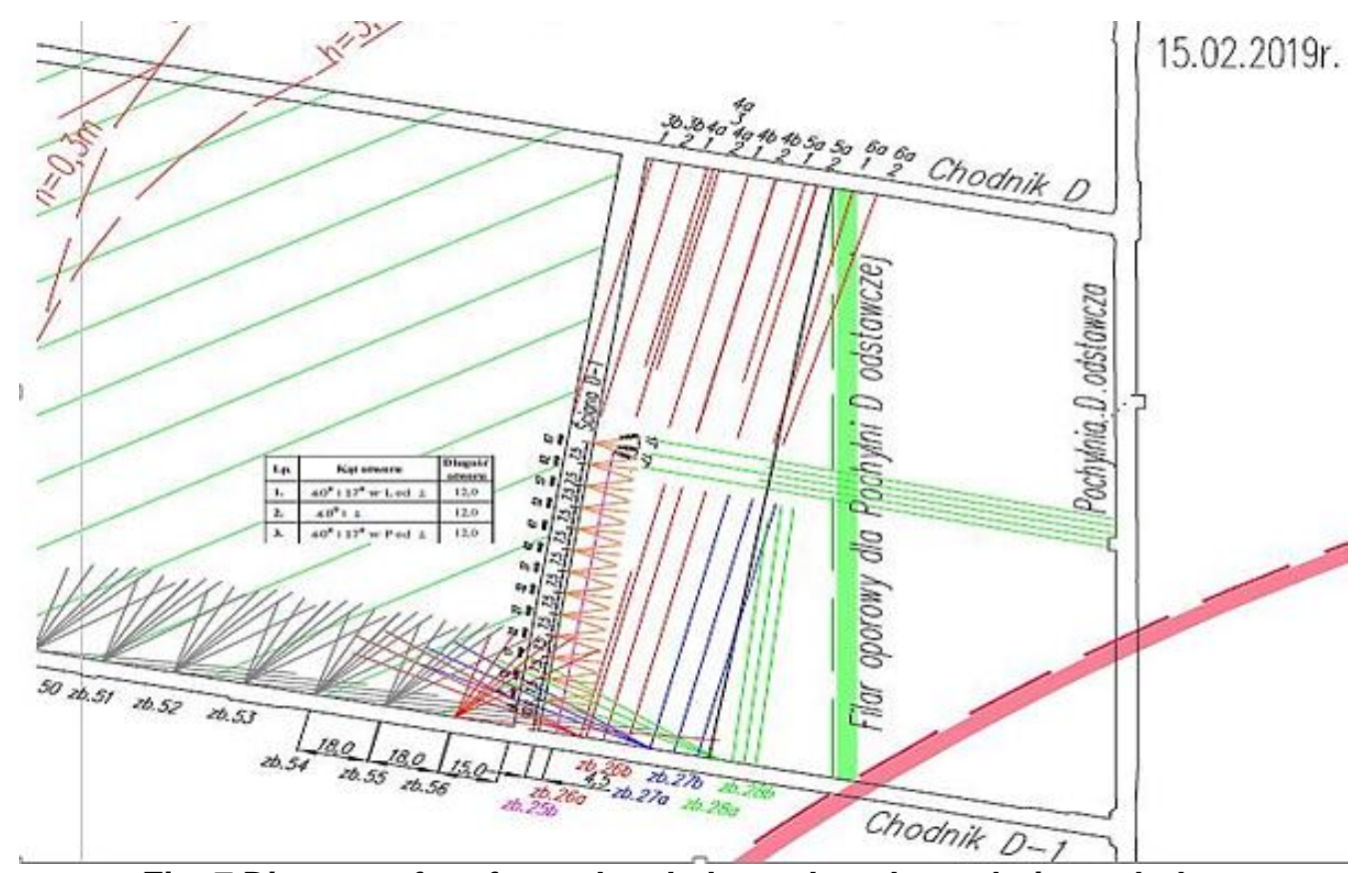

Fig. 7 Diagram of performed and planned methane drainage holes in the final section of longwall D-1, seam $358 / 1$

As agreed, on the same day, extended methane prophylaxis began, which among others involved shock blasting for each $3 \mathrm{~m}$ of face advance, from section number 70 towards Gallery D, at a mutual distance every 10 sections of the powered support, with a series of holes about $3 \mathrm{~m}$ long.

On January 7, 2019, at 20.30, shock blasting was performed in accordance with the findings of the above mentioned Team. The works did not lead to an increased methane release or exceedance of permissible methane concentrations. After blasting, mining works began in the longwall and, next, at approx. $22^{15}$ the permissible methane concentrations were exceeded on the automatic methanometric sensors in the area of Longwall D-1, in seam 358/1, due to an increased methane release after a lump of coal measuring approximately $4 . \mathrm{m} \times 1 . \mathrm{m} \times 0 . \mathrm{m}$ collapsed in section 92-95. As a result of this incident, the following exceedances of permissible methane concentration were recorded:

- sensor No. 773 (Longwall D-1 under the face conveyor extension) - max. $16.1 \%$ (5 min. $20 \mathrm{sec}$ ),

- sensor No. 774 (Longwall D-1 in a distance of 2-3 m from Gallery D-1) - max. $2.6 \%$ ( 46 sec.),

- sensor No. 775 (Longwall D-1 in a distance of $2-5 \mathrm{~m}$ to the west from the powered support roof bar) - max. 3.1\% (47 sec.), 
- sensor No. 759 (Gallery D-1 in a distance of approx. 50m to the west from the longwall) - max. $8.6 \%$ (8 min. $30 \mathrm{sec}$.),

- sensor No. 777 (Gallery D-1 in a distance of approx. 50m to the west from the beginning of the longwall) - max. 2.6\% (4 min. $17 \mathrm{sec}$.),

- sensor 778 (Gallery D-1 in a distance of max. 10 m from Ventilation Ramp D) $-\max .2 .4 \%$ (3 min. $26 \mathrm{sec}$.),

The amount of methane released was ca $180 \mathrm{~m}^{3} \mathrm{CH}_{4}$.

On 07.01.2019 at 22.20 mining works in seam 358/1 with Longwall D-1 were stopped until further exploitation conditions were determined based on the opinion of the Mine Team responsible for the identification and combating of methane hazard, who worked in cooperation with specialists.

On 08.01.2019, measurements of gas and rock outburst hazard indications were carried out in Longwall D-1, seam 58/1 in the area with an increased outflow of methane. The obtained maximum values of outburst parameters measurements have been presented in Table 2.

Table 2 Values of outburst indicators measurements in longwall D-1, seam 358/1

\begin{tabular}{|c|c|c|c|}
\hline $\begin{array}{c}\text { Location of hole in } \\
\text { Longwall D-1 } \\
\text { Seam 358/1 }\end{array}$ & $\begin{array}{c}\text { Desorption } \\
\text { intensity } \\
\text { index [kPa] }\end{array}$ & $\begin{array}{c}\text { Number } \\
\text { of borings } \\
{\left[\mathbf{d m}^{\mathbf{3}} / \mathbf{m}\right]}\end{array}$ & $\begin{array}{c}\text { Hardness according } \\
\text { to Protodiakonow }[-]\end{array}$ \\
\hline Section 80 & 1.10 & 2.8 & 0.44 \\
\hline Section 78 & 0.71 & 2.7 & 0.41 \\
\hline Section 97 & 0.69 & 2.6 & 0.44 \\
\hline
\end{tabular}

On January 9, 2019 at approx. $10^{20}$, bursting and degassing blasting was carried out in Longwall D-1, in seam 358/1 in accordance with the decisions taken at the meeting of the Mine Team for the identification and control of methane hazard, with the participation of specialists. After the blasting works, it was found that the amount of methane released reached ca $95 \mathrm{~m}^{3}$. During the exploitation of seam 358/1 carried out by the workers of subsequent two shifts on 09.01.2019, there was no exceedance of admissible methane concentrations in the longwall and along the route of air drainage from the longwall. Therefore, the above mentioned blasting works were continued cyclically.

On 09.01.2019 the absolute methane-bearing capacity of the longwall area was $41.8 \mathrm{~m}^{3} \mathrm{CH}_{4} / \mathrm{min}$, with methane drainage of $20.6 \mathrm{~m}^{3} \mathrm{CH}_{4} / \mathrm{min}$. The calculated criterial methane-bearing capacity reached $57 \mathrm{~m}^{3} \mathrm{CH}_{4} / \mathrm{min}$ and was lower than the absolute methane-bearing capacity in the longwall by $15.2 \mathrm{~m}^{3} \mathrm{CH}_{4} / \mathrm{min}$.

On 18.01.2019, at approx. $22^{58}$ the permissible methane concentrations on the automatic methanometric sensors in the area of Longwall D-1, seam 358/1 were exceeded due to an increased methane release after sliding of a coal lump in section 70-71. As a result of this incident, the following exceedances of permissible methane concentration were recorded on:

- sensor No. 740 (Longwall D-1, halfway along the length of the longwall, i.e. section number 65$)$ - max. $3.4 \%$ (13 sec.),

- sensor No. 774 (Longwall D-1 in a distance of 2-3 m from Gallery D-1) - max. $4.1 \%$ (2 min. $50 \mathrm{sec}$.), 
- sensor No. 775 (Gallery D-1 in a distance of $2-5 \mathrm{~m}$ to the west from the powered support roof bar) - max. 7.3\% (4 min. $39 \mathrm{sec}$.),

- sensor No. 759 (Gallery D-1 in a distance of approx. $50 \mathrm{~m}$ to the west from the longwall) - max. 2.8\% (3 min. $24 \mathrm{sec}$.),

- sensor No. 777 (Gallery D-1 in a distance of max. $50 \mathrm{~m}$ to the west from the beginning of the longwall) - max. 2.3\%,

- sensor No. 778 (Gallery D-1 in a distance of max. 10 m from Ventilation Ramp $D-\max 2.1 \%$ (2 min. 7 sec.).

The amount of methane released was approximately $164 \mathrm{~m}^{3} \mathrm{CH}_{4}$.

On January 21, 2019 at approx. $22^{13}$ exceedances of permissible methane concentrations were recorded by the automatic methane measurement sensors in the area of Longwall D-1 in seam 358/1, which was caused by an increased methane release. It was also found that there was no roof caving behind the powered support in sections 72 to 77 . The above caused increased stresses on the solid coal in the face front and led to a coal layer collapse in the area of sections 65-70, causing a dynamic release of methane from the coal wall. As a result of this incident, the following exceedances of permissible methane concentration were recorded on:

- sensor No. 740 (Longwall D-1, halfway along the length of the longwall, i.e. section number 65$)$ - max. $24.6 \%$ ( $1 \mathrm{~min} .46 \mathrm{sec}$.),

- sensor No. 774 (Longwall D-1, in a distance of 2-3 m from Gallery D-1) - max. $3.7 \%$ (2 min. $49 \mathrm{sec}$.),

- sensor No. 775 (Gallery D-1, in a distance of 2-5 m to the west from the powered support roof bar) - max. 3.9\% (2 min. $41 \mathrm{sec}$.),

- sensor No. 759 (Gallery D-1, in a distance of ca $50 \mathrm{~m}$ to the west of the longwall) - max. 2,0\% (1 min. 6 sec.),

- sensor No. 773 (Gallery D-1, in a distance of max. 50m to the west from the beginning of the longwall) - max. $2.0 \%$ (3 sec).

The amount of methane released was approximately $54 \mathrm{~m}^{3} \mathrm{CH}_{4}$.

On January 23, 2019 at approx. $1^{41}$ the permissible methane concentrations were exceeded on the automatic methanometric sensors in the area of Longwall D-1 in seam 358/1, due to an increased methane release after a coal lump collapsed in the area of sections 64-71. As a result of this incident, the following exceedances of the permissible methane concentration were recorded on:

- sensor No. 773 (Longwall D-1, under the face conveyor extension, not active) $-\max .3 .6 \%$ (20 sec.),

- sensor No. 740 (Longwall D-1, halfway the length of the longwall, i.e. section number 65 ) - max. $24.4 \%$ (4 min. 59 sec.),

- sensor No. 774 (Longwall D-1, in a distance of 2-3 m from Gallery D-1) - max. $25.6 \%$ (the sensor was damaged),

- sensor No. 775 (Gallery D-1, in a distance of 2-5 m to the west from the powered support roof bar) - max. 2.5\% (44 sec.),

- sensor No. 759 (Gallery D-1, in a distance of approximately $50 \mathrm{~m}$ to the west from the longwall) - max. 3.2\% (4 min. $15 \mathrm{sec}$.), 
- sensor No. 777 (Gallery D-1, in a distance of max. $50 \mathrm{~m}$ to the west from the beginning of the longwall) - max. $2.2 \%$ (2 min. 51 sec.),

- sensor No. 778 (Gallery D-1, in a distance of max. 10m from Ventilation Ramp D) $-\max .2 .0 \%$ (1 $\min .22 \mathrm{sec}$.).

The amount of methane released was approximately $185 \mathrm{~m}^{3} \mathrm{CH}_{4}$.

On February 6, 2019, at approx. $18^{33}$ exceedances of permissible methane concentrations were recorded by automatic methanometric sensors in the area of Longwall D-1 in seam 358/1, which once again were caused by an increased methane release after sliding of a coal lump with shale - this time in the area of sections 49-53. As a result of this incident, the following exceedances of the permissible methane concentration were recorded on:

- sensor No. 774 (Longwall D-1, in a distance of 2-3 m from Gallery D-1) - max. $11.5 \%$ (6 min. $30 \mathrm{sec}$.),

- sensor No. 775 (Gallery D-1, in a distance of 2-5 m to the west from the powered support roof bar) - max. 9.4\% (4 min. $45 \mathrm{sec}$.),

- sensor No. 759 (Gallery D-1, in a distance of approximately $50 \mathrm{~m}$ to the west of the longwall) - max. $4.2 \%$ (5 min. $01 \mathrm{sec}$.),

- sensor No. 777 (Gallery D-1, in a distance of max. $50 \mathrm{~m}$ to the west from the beginning of longwall) - max. $2.8 \%$ (4 min. $58 \mathrm{sec}$.),

- sensor No. 778 (Gallery D-1, in a distance of max. 10 m from Ventilation Ramp D) - max. 2.0\% (43 sec.),

- sensor No. 779 (Ventilation Ramp D, in a distance of ca $10 \mathrm{~m}$ to the north from Gallery D-1) - max. 2.1\% (2 min. $17 \mathrm{sec}$.).

The amount of methane released was approximately $203 \mathrm{~m}^{3} \mathrm{CH}_{4}$.

Due to the repeated increased release of methane during the exploitation of seam 358/1 with Longwall D-1, and the ineffectiveness of preventive measures and actions aimed at minimizing the methane hazard, on February 6 , 2019 it was decided to stop the exploitation of seam 358/1 with Longwall D-1.

On February 7, 2019, the Mine Team for Methane Hazard Identification and Control and for Blasting Works Safety had a meeting with specialists, during which it was decided to shorten the panel length by approximately $37 \mathrm{~m}$ (depending on the position of the face front in relation to the abandonment stage) and take necessary technical and organizational measures enabling safe preparation of Longwall D-1 in seam 358/1 for its abandonment.

\section{CONCLUSIONS}

1. The above described incidents indicate the existence of zones in seam $358 / 1$ where the methane-bearing capacity is so high that even preventive measures and the introduction of additional rigours of works did not allow for the complete elimination of gas-geodynamic phenomena and avoidance of danger to the people employed.

2. Irrespective of the existing legal requirements and their rigorous application, the experiences gathered in part " $D$ " of the seam show the level of danger when conducting works under conditions of the methane and gas and rock 
outburst hazard. The nature of gas-geodynamic phenomena is so complicated and unpredictable that it forces the necessity of continuous search for new principles of identifying the outburst threat and its ongoing monitoring with view of current conditions in the mine.

3. The gas and rock outburst hazard is influenced by many factors, which are completely different for each seam or part of the deposit. The interaction of individual factors has a significant impact on the performance of the initial assessment of methane and outburst threat. It is therefore necessary to increase the accuracy of hazard identification by conducting its multiparameter analysis, taking into account factors and parameters that describe physical, mechanical, gaseous, tectonic and mining properties shaping the state of threat of gas and rock outbursts in hard coal mines.

4. The above incidents show how important is continuous verification of knowledge related to the forecasting of the outburst threat on the basis of ongoing observations of works. Research centres need to carry out investigations and search for new fast and effective methods of forecasting, which are absolutely necessary for the mining industry.

\section{REFERENCES:}

Jakubów A., Tor A., Tobiczyk St. (2003) Wyrzut metanu i skał w drążonej lunecie rurowej do szybu II na poziomie $1000 \mathrm{~m}$ w KWK Pniówek - okoliczności, przyczyny i skutki. Materiały Szkoły Eksploatacji Podziemnej, Wyd. CPPGSMiE PAN. Wykłady, nr 25. Kraków.

Majcherczyk T., Jakubów A., (2007): Zagrożenia gazodynamiczne w kopalniach Jastrzębskiej Spółki Węglowej S.A.

Stączek A, Simka A, (2004) Graniczny wskaźnik intensywności desorpcji gazu z węgla charakteryzujący stan zagrożenia metanowego oraz wyrzutami metanu i skał Prace Naukowe GIG Górnictwo i Środowisko Kwartalnik 3/2004

Tor A., Jakubów A. (2006) Wyrzuty metanu i skał w kopalniach Jastrzębskiej Spółki Węglowej S.A. Materiały 4. Szkoły Aerologii Górniczej, Kraków, pp. 159-175.

Wasilewski St., Zmarzły M. (2018) Gwałtowne wypływy metanu w wyniku zjawisk gazogeodynamicznych w KWK „Borynia-Zofiówka-Jastrzębie” Ruch „Zofiówka”, Przegląd Górniczy 2018

Wasilewski St. (2009) Nowoczesne metody zwiększenia bezpieczeństwa załóg w aspekcie zagrożenia wyrzutami węgla i metanu w kopalniach eksploatujących węgiel kamienny. Raport projektu badawczo-rozwojowego N R09 0004 04, Kraków.

Zmarzły M. (2017) Rygory prowadzenia robót przygotowawczych w warunkach zagrożenia wyrzutami metanu i skał w Ruchu "Zofiówka". Materiały 9. Szkoły Aerologii Górniczej, Białka Tatrzańska, pp. 341-359.

Materiały kopalniane oraz Protokoły Kopalnianego Zespołu ds. Zwalczania Zagrożenia Metanowego oraz Wyrzutami Metanu i Skał, JSW S.A. KWK „Budryk” 20122019.

Polskie przepisy górnicze: Rozporządzenie Ministra Środowiska z dnia 29 stycznia 2013 r. w sprawie zagrożeń naturalnych w zakładach górniczych oraz Załącznik nr 3 do Rozporządzenia Ministra Energii z dnia 23 listopada 2016r. w sprawie szczegółowych wymagań dotyczących prowadzenia ruchu podziemnych zakładów górniczych.

WUG, (2006): Wnioski Komisji powołanej przez Prezesa WUG dla zbadania przyczyn i okoliczności wyrzutu metanu i skał oraz wypadku zbiorowego zaistniałego w dniu 22.11.2005r. w KWK „Zofiówka” 
WUG, (2007): Zagrożenie wyrzutami gazów i skał

\begin{abstract}
.
The nature of gas-geodynamic phenomena is so complicated and unpredictable that it forces the necessity of continuous search for new principles of identifying the outburst threat and ongoing monitoring of this threat with view of current conditions in the mine. After the incidents in JSW S.A, the mines carrying out works in seams threatened with outbursts, upon their own initiative introduced additional rigours and increased the frequency of measurements and tests regardless of the existing legal requirements. Incidents that have taken place in KWK "Budryk" in recent years show how important is continuous verification of knowledge related to the forecasting of the outburst threat on the basis of ongoing observations of works. The local occurrence of a zone characterized by high methane-bearing capacity in the coal seam, even after taking preventive measures and introducing additional rigorous did not allow for the complete elimination of gas-geodynamic phenomena and avoidance of danger to employed people.
\end{abstract}

Keywords: outbursts of methane and coal, methane hazard, gas-dynamic phenomena, transient states of air parameters, mine monitoring systems 